JNUS:Journal of Nahdlatul Ulama Studies

Vol. 2, No. 2, Juli 2021: p. 101-118. DOI: 10.35672/jnus.v2i2.101-118

Website: http://jnus.lakpesdamsalatiga.or.i d/index.php/jnus/index

\title{
The Concept of Husnul Khotimah in the Syiir of Erang- erang Sekar Panjang by Charismatic NU Kyai Named Muhammad Siraj: A Study of Hermeneutics
}

\author{
Ithafur Rahman \\ LAIN Salatiga \\ Ithafurrahman@iainsalatiga.ac.id
}

\begin{abstract}
Syiir Erang-erang Sekar Panjang was written by a charismatic NU kyai named K.H. Muhammad Siraj Payaman Magelang. Writing poetry is like an expression full of meaning and bound to the conventions of old poetry. However, on the other hand there is leeway to play with the convention. The theory to explore the meaning of this poem is the phenomeological hermeneutics theory. The phenomenological approach tries to open meaning from lingua interpretation to philosophical interpretation. The method used in this research is the dialectical method. The working mechanism of dialectics consists of thesis, antithesis, and synthesis. The results of this study indicate that Syiir Erang-erang Sekar Panjang contains a deep philosophical meaning related to death, namely the deconstruction of lay views regarding death. This verse states that death is only an effect of life and is precisely the beginning of the next life, namely life in the grave and the hereafter. In addition, the concept of husnul khotimah is also found in this syiir which consists of recommendations and prohibitions. There are six recommendations in this syiir, namely nrima, loma, food gathering, performing fardhu prayers, obedience and repentance, and always remembering death. There are five prohibitions contained in this verse, namely the prohibition of excessive love of the world, the prohibition of predicting the world, the prohibition of always feeling lacking, the prohibition of ambition to seek the world, and the prohibition of accumulating wealth.
\end{abstract}

Keywords: Husnul Khotimah, Syiir, Kyai, NU, Hermeneutics

\begin{abstract}
Abstrak
Syiir Erang-erang Sekar Panjang ditulis oleh seorang kyai kharismatik NU bernama K.H. Muhammad Siraj Payaman Magelang. Penulisan syiir ini tidak ubahnya seperti ungkapan sarat akan makna dan terikat pada konvensi puisi lama. Akan tetapi, di sisi lainnya terdapat kelonggaran mempermainkan konvensi tersebut. Teori untuk mengupas makna pada syiir ini yaitu teori bermeneutics fenomeologis. Pendekatan fenomenologi berusaha membuka makna mulai dari interpretasi lingua sampai pada interpretasi filsafati. Metode yang digunakan dalam penelitian ini adalah metode dialektika. Mekanisme kerja dialektika terdiri atas tesis, antitesis, dan sintesis. Hasil penelitian ini menunjukkan bahwa Syïr Erang-erang Sekar Panjang mengandung makna filosofis yang mendalam terkait dengan kematian, yaitu pendekonstruksian pandangan awam terkait kematian. Syiir ini
\end{abstract}


JNUS: Journal of Nahdlatul Ulama Studies, Vol. 2, No. 2, Juli 2021: 101-118

menyebutkan bahwa kematian hanya sebuah efek daripada kehidupan dan justru merupakan awal dimulainya kehidupan berikutnya, yaitu kehidupan di alam kubur dan akhirat. Selain itu, juga ditemukan konsep husnul khotimah dalam syiir ini yang terdiri atas anjuran dan larangan. Anjuran dalam syiir ini ada enam yaitu nrima, loma, golek pangan, menjalankan shalat fardhu, taat dan taubat, dan senantiasa mengingat mati. Adapun larangan yang terdapat dalam syiir ini ada lima yaitu larangan mencintai dunia berlebihan, larangan meramal dunia, larangan selalu merasa kurang, larangan berambisi mencari dunia, dan larangan menumpuk harta.

Kata Kunci: Husnul Khotimah, Syiir, Kyai, NU, Hermeneutika

\section{INTRODUCTION}

Syiir is one of the oldest types of poetry originating from Persia and has been brought into the archipelago along with the arrival of Islam. The word syiir comes from the Arabic syu'ur which means feeling. The word syu'ur developed into syi'ru which means poetry in a general sense.

The form of syiir is similar to that of poetry with stanzas. Writing poetry is like an expression that is full of meaning and bound to the conventions of old poetry (pantun), but on the other hand there is leeway to play with the convention (A. Teeuw, 1983: 4).

Syiir was allegedly born and developed in a boarding school with the basic Nadhatul Ulama (NU). The use of the Arabic pegon script strengthens the argument that this syiir work has an Islamic breath and developed in Islamic boarding schools. The content of syiir which is full of Islamic teachings (Djamaris, 1984:103) is said to have special properties when compared to other works of fiction.

Erang-erang Sekar Panjang is one of the popular poems in the community, especially among NU. It is often heard in the NU jamiyahs chanting the poem Erang-erang Sekar Panjang such as, Muslim studies, prayer gatherings, as well as praise between the call to prayer and iqamah. Judging from its appearance, this syiir was composed by a NU kyai named K.H. Muhammad Siradj. He is a charismatic NU kyai figure from Payaman Magelang, Central Java. During his life he once studied in Makkah with K.H. Cholil Bangkalan Madura, K.H. Dalhar Watucongol, and K.H. Hashim Asy'ari Tebuireng. K.H. Muhammad Siraj is one of the kyai who participated in the struggle against colonialism through religious channels, namely the Hezbollah army with K.H. Dalhar Watucongol. In fact, he is famous as a kyai carrying NU in the area where he was born. In 1930, he founded an NU Islamic boarding school which was named Pondok Sepuh. The uniqueness of this cottage is that all the students are 
elderly. He teaches his students religious sciences based on NU combined with Javanese cultural customs. It can be said that NU is a fighting house for K.H. Muhammad Siraj until the end of his life.

Writing the Erang-erang Sekar Panjang poem is like an expression that is full of meaning and bound to the conventions of old poetry (pantun), but on the other hand there is leeway to play with the convention (A. Teeuw, 1983: 4). In addition, this syiir is also full of meaning in it. Therefore, Erang-erang Sekar Panjang is included in the category of poetry.

The content of the poem Erang-erang Sekar Panjang gives a picture in the form of pitutur luhur (good advice) which is delivered in the form of sasmita (sign). These signs are interrelated and are expected to form a complete meaning. The sublime words contained in this poem are thought to contain many messages about death, among them are the process of life's journey when about to leave the body, the process of natural transfer, the state of the grave, and the concept of good life in order to prepare for death husnul khotimah.

Based on this background, the problems formulated in this study are 1) what is the philosophical meaning contained in the syiir Erang-erang Sekar Panjang? and 2) how is the concept of husnul khotimah contained in the poem Erang-erang Sekar Panjang?

The purpose of this study is to explore the meaning of the syiir Erangerang Sekar Panjang. The meaning that will be discussed in this verse aims to dissect and find the concept of husnul khotimah contained in this syiir.

Previous research that can be used as a literature review in this study is the research conducted by Dr. Abdullah, M. Hum. The research conducted by Abdullah (2006) entitled Deconstruction of Islamic Boarding School Literature. One of these studies is examining the material object of the Erang-erang Sekar Panjang poem by Kyai Muhammad Siraj. The research conducted by Abdullah on the poetry of Erang-erang Sekar Panjang focused on text editing and the eschatological aspects contained in it. The next research that can also be used as a reference is the thesis of Ithafur Rahman, M.Hum (2016) with the title Message of Death in Syiir Erang-erang Sekar Panjang by Kyai Muhammad Siraj. The focus of research conducted by Rahman (2016) is on the message of death contained in Syiir Erang-erang Sekar Panjang. The difference between this research and previous research is in the focus of the research. This research focuses on the concept of husnul khotimah contained in the poem Erang-erang Sekar Panjang by K.H. Muhammad Siradj.

The theory used to explore the meaning of this poem is Heiddeger's Hermeneutics theory or what is often called phenomeological hermeneutics. Hermeneutics or hermeneutics is the Indonesianization of the English word 
JNUS: Journal of Nahdlatul Ulama Studies, Vol. 2, No. 2, Juli 2021: 101-118

hermeneutics. The words hermeneutics in English were transferred from the Greek word hermeneutice. The first person to introduce this term was Homer, the author of the famous epic Iliad who lived around the 6th century BC (Hadi, 2008: 28).

Hermeneutics is a new way of dealing with language. Ricoeur (1977: 146) explains that text is a standardized discourse through language. What is standardized by writing is discourse that can be spoken, but discourse is written because it is not spoken. Texts are discourses conveyed in writing. Hermeneutics or interpretation theory can be traced back to classical western civilization originating in Judea, although modern views on it tend to begin with the work of Scleiermacher, one of the famous German romantics. Before modern times hermeneutics devoted attention to how to read religious texts such as the Bible (Newton, 1990: 9).

Heidegger's view of hermeneutics was chosen because this theory allows things to be manifested as they are, without being forced by the categories given. This means a reversal of direction that is characterized by a person, not something that is pointed out. More than that, it is something that shows one's self. This does not assume some primitive animist understanding, but allows the recognition that the essence of true understanding is existence which is directed by the power of something to manifest itself (Eagleton, 2006:11). Heidegger uses the word hermeneutics in the context of his broader search for a more fundamental ontology. Based on this understanding, it can be said that Heidegger maintains the claim of leben (life force) against geist (humanity science) in different forms and levels (Palmer, 2003:142).

The process of interpretation is described as a circular motion and because the science of interpretation is also called hermeneutics, the term hermeneutic circle is used ((Luxemburg et al, 1984: 67). The hermeneutic model does not look for the correct meaning, but the most optimal philosophical meaning. The diversity of views in turn creates a wealth of meaning in human life, adds to the quality of aesthetics, ethics, and logic (Ratna, 2004: 46).

\section{METHODE}

The approach or perspective used is a phenomenological approach. This phenomenological approach seeks to open meaning from linguistic interpretation to philosophical interpretation. The phenomenological approach also implements theory not solely based on awareness, history and other categories, but emphasizes the emergence and existence of a reality that is found (Pradopo, 1991: 116). 
The method used in this research is the dialectical method. The dialectical method is considered the most appropriate method in this study. The working mechanism of dialectics consists of thesis, antithesis, and synthesis. The dialectical method is one element and does not need to be fused into other elements, instead individuality is maintained in addition to its interdependence. Contradiction is not meant to be one-sided. Synthesis is not a definite result, but it is the beginning of the search for the next symptom. Every literary fact can be considered as a thesis which is then negated. The existence of denial, then the thesis and antithesis as if lost or turned into a higher quality fact, namely the synthesis itself. The synthesis then becomes a thesis again, and so on until the understanding process occurs continuously. The process of understanding the dialectical method is the same as that of hermeneutics. This method is not looking for the right meaning but looking for the most optimal philosophical meaning (Ratna, 2010:52).

The data analysis techniques used in this research are heuristic reading techniques, hermeneutic reading techniques, and dialectical techniques. These three techniques aim to understand the philosophical meaning of the syiir Erangerang Sekar Panjang and to present the concept of husnul khotimah contained in it.

The work steps in this research are as follows. 1) Read literary works in the form of the Erang-erang Sekar Panjang Syiir text carefully and thoroughly. The reading is done using heuristic and hermeneutic reading techniques on each teaching as a whole. This reading technique is used to analyze the data. 2) Interpreting various events and phenomena contained in the Syiir Erang-erang Sekar Panjang text using Heidegger's concepts and dialectical methods. 3) Finding the messages of death contained in the text of Syiir Erang-erang Sekar Panjang through the results of the meaning that has been carried out.

The work steps in this research are as follows. 1) Read literary works in the form of the Erang-erang Sekar Panjang Syiir text carefully and thoroughly. The reading is done using heuristic and hermeneutic reading techniques on each teaching as a whole. This reading technique is used to analyze the data. 2) Interpreting various events and phenomena contained in the Syiir Erang-erang Sekar Panjang text using Heidegger's concepts and dialectical methods. 3) Finding the messages of death contained in the text of Syiir Erang-erang Sekar Panjang through the results of the meaning that has been carried out.

\section{DISCUSSION}


JNUS: Journal of Nahdlatul Ulama Studies, Vol. 2, No. 2, Juli 2021: 101-118

K.H. Muhammad Siraj was born in Payaman Magelang in 1878. His father was Abdul Rasyid and his mother was Siti Salamah or better known as Mbah Dul and Mbah Ndhuk. When viewed from the mother's line, the lineage of K.H. Muhammad Siraj arrived at Joko Tingkir.

In terms of seeking knowledge, he stayed and studied in Makkah with other charismatic NU clerics such as K.H. Hasyim Asy'ari and K.H. Dalhar. After returning from Makkah, he practiced his knowledge in the area where he was born, namely Payaman Magelang. He succeeded in establishing NUbreathing huts, which were named Pondok Sepuh (because the students were old) and Pondok Kidul (because it was located south of the Payaman Grand Mosque).

K.H. Muhammad Siraj started preach in the Magelang area by holding recitation tours in order to balance the catholic doctrine pioneered by Van Lith in Muntilan. The recitation for the first time was carried out by him containing advice so that people would want to carry out Islamic law. The pattern of preach carried out by him is closely related to NU culture, namely by syncreitisme cultural arts with Islam. One of them is by wrapping the advice of faith and Islam in the form of a song called syiir. One of the well-known syiir and still alive today is the syïr Erang-erang Sekar Panjang.

Syiir Erang-erang Sekar Panjang was written by Kyai Muhammad Siradj in the village of Payaman Magelang in 1351 Hijri year or coinciding with 1931 AD. The number of the year of writing this verse is written on the front cover page of the verse text. Based on the number of years mentioned above, it can be traced that the condition of the people at that time was still classified as an abangan society. In cultural reality, the abangan society is usually still very loose with the rules held by the students, mainly related to Islamic law. In addition, the people of that era were still influenced by pre-Islamic culture, namely Hindu-Buddhist.

The background of the Payaman community is as mentioned above, so Kyai Muhammad Siradj wishes to insert a piece of advice that breathes Islam, but does not necessarily change the culture that was firmly held by the people at that time. The advice in the form of Islamic teachings was conveyed by Kyai Muhammad Siraj through the syiir Erang-erang Sekar Panjang. The recitation of the sung poetry is like an art of singing that has artistic value and is entertaining. Although artistic and entertaining, this syiir when viewed from its essence is very full of Islamic values.

Kyai Haji Muhammad Siraj in writing this syiir uses Arabic letters pegon, but the language used is Javanese. Pegon Arabic letters are Arabic letters without vowels (punctuation marks), but the spelling has been adjusted to Latin letters. The use of different characters and languages is what makes it interesting for the 
readers. The recitation of this syiir is limited to those who master the Arabic pegon reading and master the Javanese language. The use of the Arabic pegon script identifies that this literary work called syiir has an Islamic breath and develops in a Nahdhatul Ulama (NU)-based Islamic boarding school.

Syiir Erang-erang Sekar Panjang begins with the use of Arabic as the opening. The pledge of testimony which is a mandatory requirement as a Muslim (pillars of Islam) is used to begin this poem, namely the sentence syahadatain. The writing of the poem Erang-erang Sekar Panjang by Kyai Muhammad Siraj is not just an essay by him. However, the writing of this poetry is based on the Qur'an, Hadith, and previous books that are already well known. Excerpts from the Quran, the Quran, the Hadith, the famous book (the advice I gave is based on the Quran, hadith, and famous books) confirm that the writing of poetry is not the origin of writing according to the author's experience, but also based on accountable reference sources.

Syiir Erang-erang Sekar Panjang written in 31 chapter. Chapters in this syiir are chapter bungah ana donya, chapter jangka donya, chapter pecat nyawa, chapter eling pati, chapter beja cilaka kubur, chapter aja ngarep-arep mulyane awak, chapter nusahe lenderat, chapter uwat, chapter neraka suwarga kapisan, chapter golek selamet, chapter pitakonan kubur, chapter alane ngasa-asa donya, chapter sambate wong ana kerandha, chapter kewan krungu sambat, chapter golek bandha gentayangan, chapter keneban lawang tobat, chapter wekase wong ana kerandha, chapter susahe wong kubur, chapter bekti kang maha suci, chapter amal ala becik ana kubur, chapter golek pangan,chapter dhawuhe kanjeng nabi, chapter alane numpuk donya, chapter pangan kanggo ngibadah, chapter bekti bapa biyung, chapter apike titah lan alane, chapter ngelingi awak, chapter tambane susahe awak, chapter tambane larane awak, chapter tambane larane ati, dan chapter pitutur dhateng sedherek.

The analysis of the syiir Erang-erang Sekar Panjang dissects the philosophical meaning in it. Dissecting the philosophical meaning of this verse uses the dialectical method. This method will explore the philosophical meaning through the whole-part-whole concept. Thus, this syiir will be described one by one in each stanza to reveal the philosophical meaning in it.

After a thorough analysis of the philosophical meaning of this verse, it can be concluded that the syiir Erang-erang Sekar Panjang by Kyai Muhammad Siraj Payaman contains messages conveyed to readers related to the balance of life in the world and the hereafter. This balance of life must be carried out to achieve glory in this world and in the hereafter. Humans living in the world have to work hard for the fulfillment of daily life, but the final estuary is none other than to worship and get the pleasure of Allah SWT. 
JNUS: Journal of Nahdlatul Ulama Studies, Vol. 2, No. 2, Juli 2021: 101-118

The analysis of the Erang-erang Sekar Panjang poem does not stop at its philosophical meaning. But it still continues on the concept of husnulkhotimah contained in it. The concept of husnul khotimah referred to in this study is how to prepare yourself in order to achieve a husnul khotimah death. Birth and death are life processes that must be lived by every living being (Sholikin, 2008:360). All creatures created in the world will definitely experience these two cycles. Humans are born and in the end everything will experience a process called death. Therefore, this study seeks to bring up the concept of husnul khotimah contained in the poem Erang-erang Sekar Panjang by K.H. Muhammad Siradj.

The analysis of the concept of husnul khotimah in this poem is done through the stage of reading and interpretation of the text of the poem Erangerang Sekar Panjang. The reading and interpretation of the text of this poem found two types of concepts of husnul khotimah in order to welcome death, namely in the form of encouragement and prohibition during life.

The first concept of husnul khotimah obtained in the poem Erang-erang Sekar Panjang by kyai Muhammad Siraj is in the form of encouragement. Encouragement is a message that invites to do an action. In this poem there are 6 (six) suggestions or advices that invite the reader to do an act. The encouragement conveyed in this poem is conveyed with the aim of inviting the reader to do an act in order to prepare themselves to face the phenomenon called death so as not to be wretched later. The six recommendations are as follows.

\section{Narima (Accept/Sincere)}

The first suggestion in the syiir Erang-erang Sekar Panjang is to have the nature of accepting everything that has been given. Acceptance in Javanese is often also referred to as relief. The context of the suggested attitude of nrima in this text is to accept whatever has been ordained by God. As seen in the following quote.

$\begin{array}{ll}\text { Balik sira da nrimaha } & \text { Come back you receive } \\ \text { Taninge kang Maha Mulya } & \text { His Majesty's Decree } \\ \text { Supayane urip ira } & \text { So your life } \\ \text { Ana donya bisa mulya } & \text { Being in the world can be glorious }\end{array}$

In the quote above it is explained that humans are encouraged to have an attitude of accepting with relief all that has been ordained by Allah. The attitude of always accepting brings people closer to always be grateful to Him for the gifts that have been given. With gratitude, human life in the world will be peaceful and noble. On the other hand, if humans are always dissatisfied with what they get, then their life will never be peaceful and they will always feel lacking. 
The suggestion to have an accepting attitude to this syïr is not without reason. The excerpt from the quote on the syiir Erang-erang Sekar Panjang page 15 explains that it is lumrahe para manungsa ora gelem ngrasa cukup, lamun durung sira iku omah ana ing cungkup (usually humans do not want to have enough, if they have not lived in the grave). The habit of humans who never have a sense of satisfaction and sufficient for the gifts that have been obtained is one of the reasons for the emergence of an attitude of nrima in this syiir.

\section{Loma (Donate / be Generous)}

The next suggestion given in the syiir Erang-erang Sekar Panjang is about the nature of loma (generous). The nature of generosity is essentially like giving to others. The gift referred to in this case is not only in the form of material, but also nonmaterial. People who have abundant wealth may be able to donate by giving to people in need in the form of material or money. However, for people who lack excess assets, they can also give to those in need in the form of energy or other assistance.

People who like to donate means that the person is involved in easing the burden experienced by others. The person who gives must be based on sincerity so that what is given can be a blessing. In addition to sincerity, in donating also should not be subjective, meaning should not choose and sort according to desire, but adapted to who needs. The following excerpt is an explanation of the encouragement to be generous to anyone in need
Kaping papat kudu loma
all four must be generous
maring sanak kadang ira
against your brother

Donating with the intention of helping others can be a provision to face death and landerat (day of reckoning) later, to be safe in this world and in the hereafter.

\section{Golek Pangan (Looking for a Livelihood)}

Earning a living to fulfill daily needs must be done because it is for worshiping Allah. In other words, the fulfillment of needs in the world with the aim of seeking blessings from Allah SWT. Hope gets a blessing from Allah so that in the next life (hereafter) meet safety.

\footnotetext{
Padha sira lumakua

kanggo sechapter golek pangan

Supayane urip ira

ana donya bisa aman
}

\author{
You all behave \\ to find food \\ So that your life \\ in the world to be safe
}


JNUS: Journal of Nahdlatul Ulama Studies, Vol. 2, No. 2, Juli 2021: 101-118

The quote above shows that people living in the world must earn a living for the fulfillment of life in the world, so that their life in the world can be noble and safe and peaceful. However, in looking for food, it must be intended to worship Allah, so that what is obtained can be a blessing and get a reward.

People who look for food with the aim of worship, in this verse it is mentioned that in the end when they are in the afterlife they will get a gift from God. This gift is depicted with a face that shines like the moon on the 1st of the Javanese calendar. A shining face indicates that the person gets happiness and incomparable grace from Allah.

\section{Performing Obligatory Prayers}

The suggestion to perform the fardhu prayer was conveyed in order to face death, namely how to face death with husnul khotimah. In this verse it is conveyed that one of the things that will be accounted for at the time after death is the charity of prayer. In other words, this fardhu prayer can save people from the torment of the grave and misery in the afterlife.

$\begin{array}{ll}\text { Mula sira ngelingana } & \text { Then you have to remember } \\ \text { Pumpung isib urip ira } & \text { as long as you're alive } \\ \text { Perkarane ngibadahmu } & \text { the problem of your worship } \\ \text { Rina wengi aja lena } & \text { Day and night don't forget }\end{array}$

The quote above shows that in this verse the author recommends always remembering worship. There are many kinds of worship, but in this verse it is specifically clarified that the worship in question is the worship of fardhu prayers. Fard prayer is a mandatory worship that humans must always do five times a day, namely dhubur, ashar, maghrib, isya', and shubuh.

The explanation of the obligatory prayers is mentioned several times in the syiir Erang-erang Sekar Panjang in the hope that the message can be carried out well by generations. Performing fardhu prayers regularly in accordance with the time is an effort to balance between the fulfillment of life in this world and the hereafter.

\section{Obdience and Repentance}

The exhortation to obedience and repentance is conveyed in syiir Erang-erang Sekar Panjang implicitly in the following quotation.

Aja sira ngarep-arep
Ing mulyane awak ira
Lamun ora gelem taat
Urip ira ana donya
Lamun sira ana donya
Ora taubat saka maksiat
Malaikat banjur nggada

Aja sira ngarep-arep

Ing mulyane awak ira

Lamun ora gelem taat

Urip ira ana donya

Ora taubat saka maksiat
Don't you hope

Your body's glory

If you don't want to obey

Your life when in the world

If you were in the world

Do not repent from immorality

the angel then struck 
Balung ira nganti mlesat Your bones are darting

In the quote above it is explained that people who are lucky to get glory in this world and the hereafter are people who want to obey Allah SWT. Obedience is meant in this syiir that is obedient to worship Allah. As for worship, in this verse there are two things that must be carried out, namely ndherekake prentah lan ngadohi cegah (carrying out orders and staying away from prohibitions). Everything that is commanded by Allah must be carried out and stay away from what is prohibited by Him.

In addition to giving a message to obey God, in this poem is also conveyed to always repent for mistakes that have been made. However, the delivery of the message of repentance in this poem is conveyed in negative sentences. The excerpt of the quote is lamun sira ana donya ora taubat saka maksiyat, malikat banjur nggada balung sira nganti mlesat (if you in the world do not repent of immorality, the angels then hit your bones until they break). The admonition to repent in the above quotation is followed by the punishment to be received when not carrying it out.

\section{Always Remember Death}

The next suggestion contained in the syïr Erang-erang Sekar Panjang is to remember to die. In this verse repeatedly reminds humans to always remember death. The suggestion to remember death is one of the self-control systems for worldly things. This statement does not mean putting aside the worldly, but it is necessary to be able to live a balanced life between fulfilling worldly and hereafter needs. Basically all humans who live in the world will experience a phenomenon called death.

$\begin{array}{ll}\text { Ngelingana sira iku } & \text { Remember that } \\ \text { Ora sune ana donya } & \text { Not long in the world } \\ \text { Balik mesthi sira iku } & \text { Come back for sure you are } \\ \text { Tembe mburi mancal donya } & \text { In the end died }\end{array}$

The suggestion to remember death is not only given once in this verse. However, several times it was conveyed implicitly or explicitly related to the message to always remember death. The message to remember death in this syiir is also found in the eling pati chapter. In this chapter it is recommended for humans to remember death. The quote from eling-eling sira manungsa kabeh iku bakal mati (remember that all humans will die) clearly gives a warning in the form of a suggestion to always remember death. In that chapter, the suggestion to remember death is followed by an explanation of the esoteric aspects of death itself. The aim is none other than to give a picture to humans related to the state at the time of death. 
JNUS: Journal of Nahdlatul Ulama Studies, Vol. 2, No. 2, Juli 2021: 101-118

In addition to suggestions, the concept of husnul khotimah in the syiir Erangerang Sekar Panjang is conveyed in the form of a prohibition. The prohibition in question is all messages or advice in the form of prohibitions related to death. the category of prohibition in this syiir is marked with the word aja (don't).

In the syiir Erang-erang Sekar Panjang there is a concept of busnul khotimab in the form of five (5) prohibitions, namely 1) the prohibition of loving the world, 2) the prohibition of predicting the world, 3) the prohibition of always feeling lacking, 4) the prohibition of ambition to seek the world, and 5) the prohibition of piling up. treasure. The five prohibitions are described in more detail below.

\section{Prohibition of Loving the World Excessively}

The first prohibition contained in this verse is the prohibition of loving the world. Loving the world that is meant in this verse is loving something that is worldly in nature such as wealth, objects, money, etc. This is because loving something worldly will distance oneself from Allah, even more so to forget Allah. The quote that explains the prohibition to love the world excessively is as follows.

$\begin{array}{ll}\text { Aja sira banget-banget } & \text { Don't you too } \\ \text { Nggonmu bungah ana donya } & \text { Happy in the world } \\ \text { Malaikat juru pati } & \text { the angel of the dead } \\ \text { Nglirak-nglirik maring sira } & \text { Looking at you }\end{array}$

In the quote above it is explained that humans are forbidden to love the world too much, because anything worldly is mortal '(impermanent). Saying aja sira banget-banget nggonmu bungah ana donya gives an understanding that while living in the world it is forbidden not to love the world too much. The prohibition not to love this world too much is not without reason, because in the next excerpt it is explained that while living in the human world, the angel of the interpreter died to immediately take the human life. A fragment of the quote that explains that humans during their life are supervised by a dead interpreter angel, namely malaikat juru pati nglirak-nglirik maring sira (the angel of the dead interpreter watches over you).

The message provides a prohibition accompanied by a warning to humans to always be balanced in living life, namely not to love the world too much but also to always remember life after in the world, namely death.

\section{Prohibition of Predicting the World}

The second message in the form of a prohibition contained in this syiir is the prohibition to predict the world. The phenomenon of divination abounds in all 
walks of life. In this syiir, it is emphasized not to predict the world. The reason for the prohibition to foretell the world is because the work of prophesying equally precedes the will of God.

Many fortune-tellers try to predict things that will happen in the future, but in reality they rarely come true. Therefore, in this verse, we are reminded not to predict everything that exists in this world. Humans can only try and pray, the rest is left to Allah, the Lord of the worlds. The prohibition for predicting the world is contained in the following quote.

$\begin{array}{ll}\text { Aja pisan nggonmu urip } & \text { Never you live } \\ \text { Kanggo jangka chaptere donya } & \text { To predict everything about the world } \\ \text { Pirang-pirang sing dijangka } & \text { Much is predicted } \\ \text { Arang-arang sing temanja } & \text { It rarely happens }\end{array}$

The quote above clearly provides an understanding that humans are forbidden to predict the world, because predictions are rarely realized. This means that everything in this world has been ordained by God, humans do not need to predict the world. In this verse, it is recommended that humans think more about themselves in relation to preparing for death. in other words, predicting the world is tantamount to thinking only about worldly affairs. Constantly thinking about worldly affairs, it is possible to forget things related to the afterlife, one of which is death.

\section{Prohibition Always Feel Less}

The message related to the next death in the syiir Erang-erang Sekar Panjang is the prohibition of always feeling lacking for what is obtained in this world. This prohibition reminds people to always be grateful for the blessings that God has given, even if only a little.

Phenomena that exist in society in general, many are not good at being grateful for the blessings and gifts from Allah. Most people always feel less for the favors given. In this verse such things are strictly prohibited. As seen in the following quote.

$\begin{array}{ll}\text { Aja susah kurang sandang } & \text { Don't bother wearing less } \\ \text { Kurang pangan saben dina } & \text { Lack of food every day } \\ \text { Nusabana sira iku } & \text { Take care of yourself } \\ \text { Ing lenderate awakira } & \text { During your reckoning }\end{array}$

The quotation above gives a picture of a phenomenon that happens a lot in society, which is related to dissatisfaction with what God has given. The prohibition contained in this poem intertexts from the text of the Qur'an the letter of Ibrahim verse 7 with its translation which more or less reads "Indeed, if 
JNUS: Journal of Nahdlatul Ulama Studies, Vol. 2, No. 2, Juli 2021: 101-118

you are grateful, We will surely add (favors) to you, and if you deny (My favors), then surely My punishment is painful. "

In the syiir of Erang-erang Sekar Panjang and Al-Qur'an, the letter of Ibrahim both gives advice or a message to always be grateful and not deny (disbelief) for the favors that have been given to Allah.

The prohibition of not disbelieving in the blessings of Allah is associated with the death that human beings will face. The quote from nusahan sira is in the landerate awakira "you have difficulty with the calculation / calculation of your deeds" gives an explanation that it is better to think of your own difficulties when you face the day of the calculation of human deeds than to have to worry because you always feel less in the world.

The advice in this quote clearly illustrates that humans are advised to always be grateful for Allah's favors and also balance it with worship as a provision to face the next life, namely the hereafter.

\section{Prohibition of Ambition to Seek the World}

The message of death in the form of a ban conveyed in the discussion that follows is still related to the previous prohibitions. The discussion related to the prohibitions discussed above revolves around worldly problems. The message in the form of the following prohibition is also still dwelling on worldly problems, namely the prohibition of ambition in seeking the world.

In this syiir, many emphasize the prohibition to pursue things that are worldly, because it is this worldliness that makes people forget about life after this world (afterlife). The prohibition of ambitious worldly pursuits in this poem is emphasized so that people do not forget the hereafter, because life does not only stop in the world, but life still continues (afterlife life). Here's a quote about prohibition being too ambitious in the pursuit of the world.

$\begin{array}{ll}\text { Aja sira ngasa-asa } & \text { Do not be ambitious to chase } \\ \text { Nggonmu golek, bandha donya } & \text { In search of property } \\ \text { Nggone golek sira iku } & \text { In thee seek } \\ \text { Ngasi teka liya negara } & \text { Get to another country }\end{array}$

In addition to emphasizing the prohibition of pursuing worldly ambitions, this verse is also conveyed about the advice to always remember death. Death is the second life after life on earth.

Life after living in the world is not equipped with property, but equipped with deeds of worship while living in the world. If his deeds are good, then he will be glorious when living in the hereafter. On the other hand, if during his life 
he only seeks worldliness without being balanced with good deeds of worship, then in the hereafter he will be miserable.

The prohibition of being too ambitious in pursuing the world coupled with the suggestion to remember death indirectly illustrates that after the end of life in this world, one will live the next life, namely in the realm of death. While still living in this world, balance must be applied in looking for provisions in this world and the hereafter. This is because if it comes to death, it will never be able to return to the life of the world.

The message of death related to the world does not stop here, but is still continued with the prohibition of accumulating wealth. An explanation of the death message in the form of a prohibition on accumulating wealth will be explained below.

\section{Prohibition of Accumulating Property}

The next message conveyed in the poem Erang-erang Sekar Panjang is about the prohibition of accumulating wealth. This message is still dwelling on worldly affairs. Worldly affairs are always related to the hereafter, because while living in this world, humans can find provisions to live the afterlife.

Accumulating wealth in this verse is a prohibition, because the person who accumulates the wealth of identification is a miser and stingy person. A stingy person is a person who does not want to give some of his wealth to people in need. Such a person is very hated by Allah.

The accumulated wealth will usually make people forget where the fortune comes from. This means that people who like to accumulate wealth are close to being negligent. Negligence in question is neglect in terms of worshiping Allah.

In this syiir, the prohibition of accumulating wealth is not written with the word aja (don't). However, the prohibition was conveyed accompanied by a picture of retaliation for people who during their life in this world only accumulate wealth. The following is an excerpt from the ban.

$\begin{array}{ll}\text { Lamun sira golek donya } & \text { If you are looking for treasure } \\ \text { Niyat kanggo numpuk-numpuk } & \text { Intention to pile up } \\ \text { Besuk tangi saka kubur } & \text { Tomorrow wake up from the grave } \\ \text { Dunve rai kaya kunur } & \text { Have a face like shattered }\end{array}$

The quotation above explains that the person who during his life in this world only accumulated wealth, then later in the next life will get his reward, which is the face that is destroyed due to the torment of the angels. This is because usually people who are close to wealth will be far from worship. If you have forgotten your worship and Allah SWT, then in the last day you will get the reward. 
JNUS: Journal of Nahdlatul Ulama Studies, Vol. 2, No. 2, Juli 2021: 101-118

The prohibition above is the last death message in the form of a prohibition in this subchapter. based on an analysis of the message of death in the form of a prohibition on this verse, it can be concluded that the prohibitions contained in the syiir Erang-erang Sekar Panjang are mostly prohibitions in worldly matters ranging from looking for treasure, loving wealth, to piling up wealth. In other words, the message conveyed in the form of a prohibition on this syiir is that humans live in the world should be able to apply in a balanced way in an effort to fulfill needs in the world and in the hereafter. The purpose of this balance is to be able to live happily in this world and get glory in the next life that is eternal.

\section{CONCLUSION}

Based on the reviews in the previous chapters on the poetry of Erang-erang Sekar Panjang by Kyai Muhammad Siraj, the following conclusions can be drawn in this study.

Syiir Erang-erang Sekar Panjang by Kyai Muhammad Siraj Payaman contains a very deep philosophical meaning related to the meaning of life and death. So far the layman's view regarding death is the end rather than life. However, this is not what is taught in the poem Erang-erang Sekar Panjang. In this verse it gives an illustration that death is not the end of everything. Death is only an effect of life in this world and is precisely the beginning of the start of the next life, namely life in the grave and the hereafter. In addition to providing an overview related to the concept of life and death, this syiir also provides advice as well as messages related to life and death. The message conveyed in the syiir Erang-erang Sekar Panjang is that humans can live a balanced life "balanced". The balance in question is a balance regarding the fulfillment of worldly and hereafter needs. Earning a worldly living is an effort to fulfill the needs in the world so that life can be peaceful. The fulfillment of worldly needs must also be balanced with the fulfillment of the needs of the hereafter as provisions for the hereafter. The fulfillment of the needs of the hereafter in question is to worship Allah SWT and fellow living creatures.

The concept of busnul khotimah contained in the syïr Erang-erang Sekar Panjang is of two types, namely encouragement and prohibition. The encouragement contained in the syiir Erang-erang Sekar Panjang has six (6), namely nrima (receiving), loma (generous), golek pangan (seeking livelihood), performing obligatory prayers, obedience and repentance, and always remembering the dead. As for the prohibitions contained in the syïr Erang-erang Sekar Panjang, there are 5 , namely the prohibition of loving the world excessively, the prohibition of 
predicting the world, the prohibition of always feeling less, the prohibition of ambitious seeking the world, and the prohibition of accumulating wealth.

The concept of husnul khotimah conveyed in the syïr Erang-erang Sekar Panjang is very relevant to life in the present and in the future. The relevance is seen in the teachings that encourage humans to try to find a decent life in the world. However, as a guide so as not to slip into the worldly, it is also recommended to always remember Allah through worship and remember death in order to fulfill the needs of the hereafter.

The results of this study are expected to be able to provide benefits to society in general in relation to literary works, especially Islamic boarding school literature, literary sciences, especially hermeneutic theory, as well as the results of the analysis of the literary work itself. For the future, it is recommended that this research can be continued as further research.

\section{REFERENCES}

Abdullah, Muhammad. 2006. Dekonstruksi Sastra Pesantren : Filologi, Gender, Filsafat \& Teologi Islam. Semarang: Fasindo.

Departemen Agama R.I. 1989. Al-Quran dan Terjemahannya. Semarang : Toha Putra.

Departemen Agama R.I. 2003. Pola Pembelajaran di Pesantren. Jakarta: Direktorat Jenderal Kelembagaan Agama Islam.

Dhofier, Zamakhsyari . 1982. Tradisi Pesantren: Studi Tentang Pandangan Hidup Kyai. Jakarta: LP3ES.

Djamaris, Edwar. 1984. Menggali Khazanah Sastra Melayu Klasik : Sastra Lama Indonesia. Jakarta : Proyek Penerbitan Buku Sastra Indonesia dan Daerah.

Eagleton, Terry. 2006. Teori Kesusastraan : Satu Pengenalan. (Penterjemah Muhammad HJ. Shaleh). Yogyakarta : Jalasutra.

Endraswara, Suwardi. 2003. Metodologi Penelitian Sastra Epistemologi, Model, Teori, dan Aplikasi. Yogyakarta: FBS Universitas Negeri Yogyakarta.

Faizi, Muhammad. 2013. Silsilah Intelektualisme dan Sastra di Pesantren (Sebuah Perambahan Atas Tradisi Pesantren, Sastra, dan Sastra Pesantren). http://binhadnurrohmat.com/athor/binhad.

Fuadhiyah, Ucik. 2006. Pendidikan Kebangsaan dalam Simbol dan Makna Pada Lirik Lagu Dolanan di Jawa Tengah. Skripsi : FBS Universitas Negeri Semarang.

Hadi, W.M. Abdul. 2008. Hermenentika Sastra Barat dan Timur. Jakarta : Pusat Bahasa Departemen Pendidikan Nasional.

Liu, Willy \& M. O’C. Walshe. 2010. Ajaran Budha dan Kematian. (Diterjemahkan oleh Seng Hansun). Jogjakarta : Vidyāsenā Production Vihāra Vidyāloka. 
JNUS: Journal of Nahdlatul Ulama Studies, Vol. 2, No. 2, Juli 2021: 101-118

Luxemburg, Mike Bal, Weststeijn. 1984. Pengantar Ilmu Sastra. (Diindonesiakan oleh Dick Hartoko). Jakarta : Gramedia.

Muzakka, Mohammad. 2008. Memanfaatkan Tradisi Lisan. http://www.suaramerdeka.com/smcetak/index.php?fuseaction=beritacet ak.

Newton, K.M. 1990. Interpreting the text. New York: Harvester Wheatsheaf.

Nugroho, Yusro Edy. 2000. Hermeneutika Sebuab Tawaran Model Pemahaman Bagi Manuskrip Indonesia. Makalah : Jurusan Bahasa dan Sastra Indonesia FBS Unnes.

Palmer, Richard. 2005. Hermeneutika Teori Baru Mengenai Interpretasi. Yogyakarta : Pustaka Pelajar.

Pradopo, Rachmat Djoko. 1991. Panduan Pembaca Teori Sastra Masa Kini. Yogyakarta: Gadjah Mada University Press.

Qodratillah, Meity Taqdir. 2011. Kamus Bahasa Indonesia Untuk Pelajar. Jakarta : Kementrian Pendidikan dan Kebudayaan.

Ratna, Nyoman Kutha. 2004. Penelitian Sastra : Teori, Metode, dan Teknik. Yogyakarta : Pustaka Pelajar.

Ricoeur, Paul. 1977. The Rule Of Methaphor. Diterjemahkan oleh Robert Czerny, Kathleen Mc Laughin, dan John Castello, S.J. London \& New York : Routledge Classic.

Shihab, M. Quraish. 1996. Wawasan Al-Qur'an : Tafsir Maudhu'i Atas Pelbagai Persoalan Umat. Bandung : Mizan.

Sholikhin, Muhammad. 2008. Manunggaling Kawula-Gusti :Filsafat Kemanunggalan Syekh Siti Jenar. Jakarta : Narasi.

Siraj, Muhammad. 1822. Syiir Erang-erang Sekar Panjang. Muntilan : yayasan pondok pesantren magelang.

Sumaryono, E. 2009. Hermeneutik Sebuah Metode Filsafat. Yogyakarta : Kanisius.

Tim Puslibang Lektur Keagamaan. 2003. Pedoman Transliterasi Arab Latin ; Keputusan Bersama Menteri Agama dan Menteri Pendidikan dan Kebudayaan Republik Indonesia Nomor : 158 Tabun 1987 Nomor 0543 b/u/1987. Jakarta : Proyek Pengkajian dan Pengembangan Lektur Pendidikan Agama.

Teeuw, A. 1983. Membaca dan Menilai Sastra. Jakarta : Gramedia.

Yasmadi. 2005. Modernisasi Pesantren : Kritik Nurcholish Madjid Terhadap Pendidikan Islam Tradisional. Jakarta : Ciputat Press. 